RICYDE. Revista Internacional de Ciencias del Deporte doi: $10.5232 /$ ricyde

Rev. int. cienc. deporte

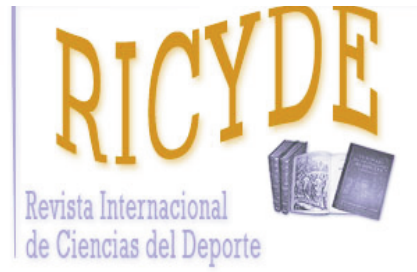

RICYDE. Revista Internacional de Ciencias del Deporte VOLUME XIV - YEAR XIV

Pages:42-54 ISSN:1885-3137

Issue: 51 - January - 2018

\title{
Basketball without borders? Similarities and differences among Continental Basketball Championships \\ ¿Baloncesto sin fronteras? Similitudes y diferencias entre los Campeonatos Continentales de baloncesto
}

\author{
Sergio José Ibáñez ${ }^{1}$, Sergio González-Espinosa², Sebastián Feu ${ }^{1}$ \& Javier García-Rubio ${ }^{3}$
}

\begin{abstract}
1.Facultad de Ciencias del Deporte. Universidad de Extremadura. Spain
2.Facultad de Ciencias de la Educación. Universidad de Extremadura. Spain

3.Facultad de Educación. Universidad Autónoma de Chile. Chile
\end{abstract}

\begin{abstract}
The analysis of technical-tactical performance indicators is an excellent tool for coaches, because it provides objective information on the actions of players and teams. The aim of this investigation was to study the performance indicators for the last continental basketball championships. Five continental championships played in 2015 were analysed for a total of 213 matches. The variables analysed were: ball possessions, point difference, points scored, one, two and three point throws attempted and scored, total and defensive and offensive rebounds, assists, steals, turnovers, blocks for and against, fouls committed and received, and evaluation. A descriptive analysis and performance profiles were carried out to characterise the sample. A one-way ANOVA and Bonferroni correction were used to identify the differences among championships. A discriminant analysis was performed to identify the performance indicators best characterising each analysed championship. The results show that there are differences among all the championships and all the performance indicators, except in three point throws scored and blocks. A specific play profile has been identified for each championship. The greatest performance profile differences were found between the Eurobasket and the Afrobasket championships, while the championships with the most similar performance indicator profiles were FIBA America and Asia Cup. These findings are useful for coaches when preparing the different possible scenarios depending on the championship and their respective opponent.
\end{abstract}

Key Words: performance analysis, competition analysis, technical-tactical performance indicators, continental championships, basketball.

\section{Resumen}

El estudio de los indicadores de rendimiento técnico-tácticos son una gran herramienta para los entrenadores, pues proporciona información objetiva sobre las acciones del deportista y del equipo. El objetivo de esta investigación fue estudiar los indicadores de rendimiento en los últimos Campeonatos Continentales de Baloncesto. Se analizaron los 5 campeonatos continentales del año 2015, un total de 231 partidos. Las variables analizadas fueron: posesiones de balón, diferencia de puntos, puntos anotados, lanzamientos de uno, dos y tres puntos anotados y lanzados, rebotes totales, defensivos y ofensivos, asistencias, robos, pérdidas, tapones a favor y en contra, faltas cometidas y recibidas, y valoración. Se llevaron a cabo un análisis descriptivo y de perfiles de rendimiento para caracterizar la muestra. La ANOVA de un factor con la corrección de Bonferroni se utilizó para identificar las diferencias entre campeonatos. El análisis discriminante permitió identificar los indicadores de rendimiento que mejor caracterizan a cada uno de los campeonatos continentales. Los resultados ponen de manifiesto que existen diferencias entre todos los campeonatos en todos los indicadores de rendimiento, salvo en los tiros de 3 puntos anotados y en los tapones. Se identifica un perfil de juego específico para cada campeonato. Las mayores diferencias en los perfiles de rendimiento se encuentran entre el Eurobasket y Africabasket, mientras que los campeonatos con un perfil más parecido en los indicadores de rendimiento son el FIBA América y Asiabasket. Estos hallazgos son de utilidad para los entrenadores a la hora de preparar los diferentes escenarios posibles en función del campeonato y rival al que se enfrenten.

Palabras clave: análisis del rendimiento; análisis de la competición; indicadores de rendimiento técnico-táctico; campeonatos continentales; baloncesto.

Correspondence/correspondencia: Sergio José Ibáñez

Facultad de Ciencias del Deporte. Universidad de Extremadura

Email: sibanez@unex.es 
Ibañez, S.J.; González-Espinosa, S.; Feu, S., \& García-Rubio, J. (2018). Basketball without borders? Similarities and differences among Continental Basketball Championships. RICYDE. Revista internacional de ciencias del deporte, 51(14), 42-54. https://doi.org/10.5232/ricyde2018.05104

\section{Introduction}

$\mathrm{M}$ odern sports practice has evolved from the preparation and analysis of competition by means of the subjective perceptions of the coaches towards an evaluation based on technical-tactical performance indicators (TTPI). The study of TTPI is a useful tool for coaches as it provides objective information about the actions of players and the team. This information allows the identification of performance indicators and competition characteristics (Hughes \& Franks, 2007). TTPI can be studied using the outcome of the game, i.e. the result. These studies analyse the competition in a static manner by means of the data from the so-called game statistics. For this they use the individual or group performance indicators analysed at the end of the competition. They permit the characterisation of the competitions and the players. Other studies analyse performance indicators during the match, directly studying play actions and interactions. These investigations analyse the play process, studying the game in a dynamic manner (Ibáñez, Feu, \& Dorado, 2003).

Studies on performance indicators normally use samples from the most representative championships in each sports discipline, due its transference to the sport context. In basketball, studies are frequently performed on the best professional leagues, the NBA or WNBA, at the top competitive level of professional leagues, as well as the World Championships. The NBA has been widely studied (García, Cañadas, \& Antúnez, 2015; Ibáñez, García, Feu, Parejo, \& Cañadas, 2009; Mikołajec, Maszczyk, \& Zając, 2013; Ribeiro, Mukherjee, \& Zeng, 2016). The best professional leagues using the FIBA regulations have also been studied, as the ACB (García, Saéz, Ibáñez, Parejo, \& Cañadas, 2009; Gómez, Lorenzo, Sampaio, Ibáñez, \& Ortega, 2008; Puente, Coso, Salinero, \& Abián-Vicén, 2015). World Basketball Championships have also been studied in different categories. In World Junior Basketball Championship (Ibáñez, Sáenz-López, Giménez, Sampaio, \& Janeira, 2003) and comparision between junior and senior (García, Ibáñez, Parejo, Cañadas, \& Feu, 2010; Sampaio, Ibáñez, \& Feu, 2004). The results of these investigations perfectly describe each competition.

Performance profiles in sport can also be defined as the collection of reliable performance indicators which show the performance of a player or team (Liu, Yi, Giménez, Gómez, \& Lago-Peñas, 2015). TTPI are not stable characteristics of sports teams, rather they vary according to situational variables, like the venue for the match and the quality of the opponent (Lago-Peñas \& Lago-Ballesteros, 2011), and the efficiency of the team (Liu et al., 2015). For this reason, performance profiles have been suggested as a stable method for identifying the typical behaviour of sports teams (Hughes, Evans, \& Wells, 2001; O'Donoghue, 2005).

In every regional basketball championship, the winning teams can be identified by specific TTPI, thus defining the performance profile in each competition according to its situational variables (Liu et al, 2015). The best national basketball teams as well as participating in their respective continental championships, have the possibility of taking part in two worldwide competitions, the Olympic Games and the World Championships. In the last few years, the teams that occupy the top positions in the medal tables come from the same continental championships (FIBA America and Eurobasket). The best ranked teams in the 2016 Olympic Games were: USA, Serbia, Spain, and Australia, with Argentina, France, Lithuania and Croatia completing the top eight. These eight teams come from three different continental championships. 
Ibañez, S.J.; González-Espinosa, S.; Feu, S., \& García-Rubio, J. (2018). Basketball without borders? Similarities and differences among Continental Basketball Championships. RICYDE. Revista internacional de ciencias del deporte, 51(14), 42-54. https://doi.org/10.5232/ricyde2018.05104

The majority of studies have focussed on identifying the TTPI which differentiate winners from losers in different scenarios, like the final point difference (García et al., 2014) or the fact of playing at home or away (García et al., 2009). There are also studies which compare performance indicators according to different performance level of competition and gender, but no studies which analyse the performance indicators among the different continental championships. Thus the general aim of this investigation was to study the TTPI in the last continental basketball championships. Specifically there was a dual objective: i) to characterise the performance indicators in the five continental championships, and ii) to identify the TTPI that differentiate and discriminate among the championships.

\section{Method}

\section{Participants}

This is a retrospective study investigating the performance indicators differentiating between five continental championships in 2015 . The sample for this study was composed of all the continental men's basketball championships held during 2015: Eurobasket, Asia Cup, FIBA Americas, Afrobasket and FIBA Oceania. A total of 231 matches were played $(n=462)$ (Table 1). The FIBA Oceania championship was eliminated from the final sample as the competition characteristics are different from those of the rest of the championships (only two teams take part and they play a two game home-and-away playoff). The FIBA competitions are characterised as having the World Championship format that is with just one match. The championships analysed were organised as a first phase round robin tournament in groups, and then a single elimination tournament among the qualified teams. The data were obtained from the official web page of the International Basketball Federation (FIBA) (http://www.fiba.com/es).

\begin{tabular}{|c|c|c|c|}
\hline & Cases & Matches & $\%$ \\
\hline Eurobasket & 158 & 79 & 34 \\
\hline Afrobasket & 96 & 48 & 21 \\
\hline FIBA America & 80 & 40 & 17 \\
\hline Asia Cup & 124 & 62 & 27 \\
\hline FIBA Oceania & 4 & 2 & 01 \\
\hline Total & 462 & 231 & 100 \\
\hline
\end{tabular}

\section{Variables}

The absolute game-related statistics gathered were: ball possessions, point difference, points scored, 2-point and 3-point field-goals (both successful and unsuccessful), freethrows (both successful and unsuccessful), offensive and defensive rebounds, steals, turnovers, assists, blocks (both performed and received), personal fouls (both committed and received) and evaluation. To avoid the contaminating effect of the game pace, the variables were normalised for 100 ball possessions per match (García, Ibáñez, Martínez De Santos, Leite, \& Sampaio, 2013; Ibáñez et al., 2003). The ball possession equation (BP) was calculated according to Oliver (2004):

$$
\mathrm{BP}=(\text { field-goals attempted })-\left(\begin{array}{c}
\text { offensive rebounds })+(\text { turnovers })+0.4 \times(\text { free-throws } \\
\text { attempted }) .
\end{array}\right.
$$

\section{Procedure}

The data were collected by the official technicians from each competition. It has been shown that data obtained with this methodology in different contexts have very good reliability (García, Ibáñez, Gómez, \& Sampaio, 2014; Sampaio, et al., 2015). Even so, to 
Ibañez, S.J.; González-Espinosa, S.; Feu, S., \& García-Rubio, J. (2018). Basketball without borders? Similarities and differences among Continental Basketball Championships. RICYDE. Revista internacional de ciencias del deporte, 51(14), 42-54. https://doi.org/10.5232/ricyde2018.05104

guarantee their validity, a subsample of five matches was analysed by two expert observers (basketball coaches with more than five years experience) using the multirater $\kappa f r e e$ index (Randolph, 2005). The results show the high level of inter-rater reliability of the data collected. The Kappa coefficients obtained was 1.0 for all the variables except assists (.91).

\section{Data analysis}

Firstly a descriptive analysis of the sample was performed, using the mean and standard deviation, to show the characteristics of each of the different competitions. Performance profiles were also performed to complete the descriptive analysis (O'Donoghue, 2005). Then a one-way ANOVA was carried out to identify the differences between competitions in the analysed variables. Bonferroni's post-hoc was used for the pairwise comparisons (Field, 2013). The effects sizes were calculated using Cohen's $d$ for the $F$ statistic. Effect sizes between .20 and .50 were considered small, between .50 and .80 were considered medium and greater than .80 were considered large (Thalheimer \& Cook, 2002). Finally, the discriminant analysis was carried out to identify the TTPI which best characterise each one of the continental championships (Ntoumanis, 2001). The structural coefficients (SCs) with values of over |.30| made it possible to identify the variables that best contributed to differentiating among the continental championships (Tabachnick, Fidell, \& Osterlind, 2001). The greater the SC value, the greater the contribution of this performance indicator to the discriminant function. The centroids indicate the championship with the greatest contribution from each performance indicator. All the analyses were carried out with the IBM SPSS 21.0 statistical package (IBM Corp., Armonk, NY, USA).

\section{Results}

In the first place, Table 2 shows the descriptive statistics as a function of the competition, and Figure 1 presents a visual image of the performance profiles. It can be seen that the fastest basketball was played in the Asia Cup, with more possessions, but not more points scored, which corresponded to the FIBA America. It was also the Asia Cup which showed the greatest point differences between winners and losers, while in FIBA Oceania and Eurobasket the teams were more equal. Eurobasket was the championship which presented the most assists, and the second to last in number of turnovers, behind FIBA Oceania.

Table 2. Means, standard deviations and differences among groups as a function of the competition

\begin{tabular}{lrrrrrrrrrr} 
& \multicolumn{3}{c}{ Eurobasket } & \multicolumn{3}{c}{ Afrobasket } & \multicolumn{3}{c}{ FIBA America } & \multicolumn{2}{c}{ Asia Cup } & \multicolumn{2}{c}{ FIBA Oceania } \\
\cline { 2 - 12 } & \multicolumn{1}{c}{$M$} & \multicolumn{1}{c}{$S D$} & \multicolumn{1}{c}{$M$} & \multicolumn{1}{c}{$S D$} & \multicolumn{1}{c}{$M$} & \multicolumn{1}{c}{$S D$} & \multicolumn{1}{c}{$M$} & \multicolumn{1}{c}{$S D$} & \multicolumn{1}{c}{$M$} & \multicolumn{1}{c}{$S D$} \\
\hline Possessions & 65.01 & 5.83 & 66.18 & 7.81 & 68.66 & 7.11 & 69.12 & 8.35 & 62.85 & 7.17 \\
Point difference & 11.61 & 9.30 & 14.42 & 10.96 & 13.78 & 10.03 & 21.51 & 17.74 & 11.00 & 1.15 \\
Points scored & 74.82 & 11.82 & 70.81 & 12.23 & 78.96 & 13.70 & 76.83 & 16.10 & 74.50 & 12.69 \\
Successful 2P field-goals & 30.76 & 7.22 & 26.11 & 6.81 & 31.03 & 6.34 & 29.68 & 6.66 & 32.58 & 6.91 \\
Unsuccessful 2P field-goals & 61.46 & 9.52 & 55.48 & 8.96 & 63.81 & 9.39 & 63.69 & 9.18 & 67.44 & 5.40 \\
Successful 3P field-goals & 10.86 & 4.10 & 10.23 & 4.52 & 10.73 & 4.67 & 11.22 & 4.10 & 12.19 & 2.11 \\
Unsuccessful 3P field-goals & 33.00 & 9.00 & 37.98 & 8.95 & 32.39 & 8.21 & 33.68 & 7.64 & 35.25 & 8.53 \\
Successful free-throws & 21.18 & 8.51 & 24.50 & 9.96 & 20.89 & 8.07 & 17.63 & 7.42 & 17.41 & 12.31 \\
Unsuccessful free-throws & 28.78 & 10.05 & 36.95 & 13.60 & 29.77 & 10.50 & 26.02 & 10.46 & 20.52 & 13.48 \\
Total Rebounds & 49.06 & 9.16 & 61.46 & 12.11 & 58.75 & 11.06 & 58.82 & 10.38 & 56.32 & 16.76 \\
Defensive Rebounds & 36.05 & 7.73 & 41.74 & 8.97 & 41.20 & 8.26 & 40.10 & 7.48 & 41.71 & 15.71
\end{tabular}


Ibañez, S.J.; González-Espinosa, S.; Feu, S., \& García-Rubio, J. (2018). Basketball without borders? Similarities and differences among Continental Basketball Championships. RICYDE. Revista internacional de ciencias del deporte, 51(14), 42-54. https://doi.org/10.5232/ricyde2018.05104

\begin{tabular}{lrrrrrrrrrr} 
Offensive Rebounds & 13.01 & 5.17 & 19.73 & 7.11 & 17.55 & 6.06 & 18.72 & 6.56 & 14.61 & 3.52 \\
Assists & 28.13 & 7.16 & 19.18 & 6.37 & 27.35 & 6.48 & 18.44 & 7.21 & 23.47 & 2.05 \\
Steals & 7.03 & 3.38 & 11.49 & 4.72 & 9.44 & 3.73 & 10.95 & 4.15 & 3.72 & 3.61 \\
Turnovers & 18.67 & 6.57 & 27.08 & 8.67 & 19.33 & 6.97 & 21.32 & 7.48 & 17.35 & 7.59 \\
Blocks & 3.86 & 2.95 & 3.98 & 2.65 & 4.11 & 2.77 & 3.59 & 2.66 & 4.01 & 3.96 \\
Fouls Committed & 33.05 & 6.45 & 34.64 & 8.59 & 30.64 & 6.24 & 27.88 & 7.76 & 24.50 & 5.14 \\
Fouls Received & 32.87 & 6.39 & 34.67 & 8.58 & 30.75 & 6.72 & 27.74 & 7.18 & 24.67 & 6.08 \\
Efficiency Index & 140.26 & 35.43 & 112.63 & 35.69 & 132.21 & 33.13 & 116.44 & 42.74 & 128.43 & 47.17 \\
\hline
\end{tabular}

The performance profiles in each competition show that, although it is the same sport played in different continental championships, there are differences in the performance indicators which specifically define what each competition is like in each region of the world. This was confirmed in the subsequent inferential analysis.

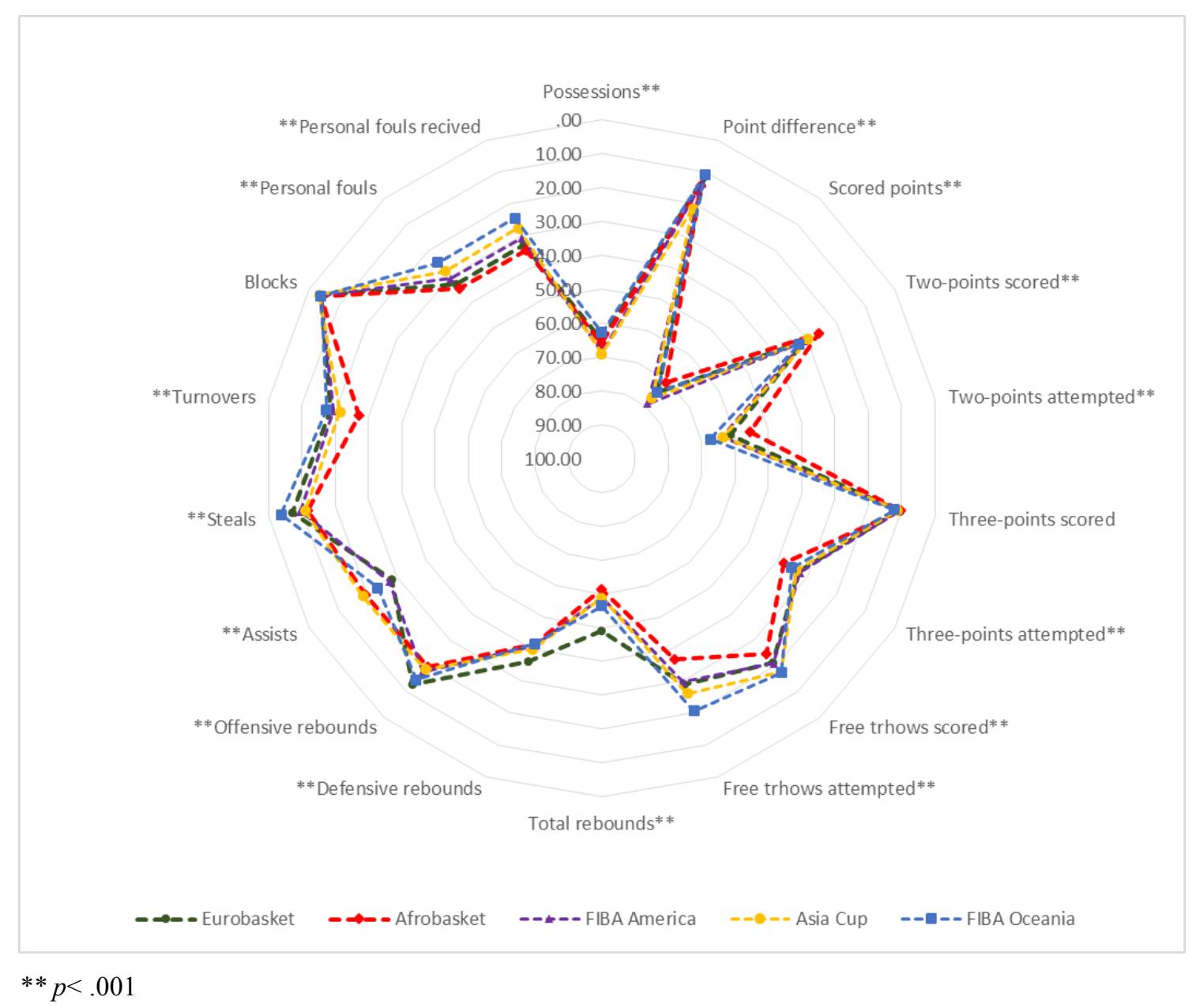

Figure 1 Performance profiles of each championship analysed. 
Ibañez, S.J.; González-Espinosa, S.; Feu, S., \& García-Rubio, J. (2018). Basketball without borders? Similarities and differences among Continental Basketball Championships. RICYDE. Revista internacional de ciencias del deporte, 51(14), 42-54. https://doi.org/10.5232/ricyde2018.05104

Table 3 shows the results of the ANOVA and post-hoc test with the effect sizes. It can be seen that the most similar championships regarding performance indicators were those of America and Asia. In contrast, the championships which differed most were those of Europe and Africa. Similarly, the performance indicator which most differentiated among the championships and presented the largest effect size was that of assists. The TTPI that differentiated least among the different teams were 3 point shots scored and blocks, which showed no statistically significant differences.

Table 3. Results of the differences among groups

\begin{tabular}{|c|c|c|c|c|c|c|c|c|c|c|c|c|c|c|}
\hline & \multicolumn{6}{|c|}{$A N O V A$} & \multicolumn{6}{|c|}{ Post Hoc } & \multirow{2}{*}{\multicolumn{2}{|c|}{ Amer-Asia }} \\
\hline & \multirow[b]{2}{*}{$F$} & \multirow[b]{2}{*}{$P$} & \multicolumn{2}{|c|}{ Euro-Afro } & \multicolumn{2}{|c|}{ Euro-Amer } & \multicolumn{2}{|c|}{ Euro-Asia } & \multicolumn{2}{|c|}{ Afro-Amer } & \multicolumn{2}{|c|}{ Afro-Asia } & & \\
\hline & & & $p$ & $d$ & $p$ & $d$ & $p$ & $d$ & $p$ & $d$ & $p$ & $d$ & $p$ & $d$ \\
\hline Possessions & 9.249 & .00 & 1.000 & 0.16 & .002 & 0.56 & .000 & 0.57 & .177 & 0.33 & .024 & 0.36 & 1.000 & 0.05 \\
\hline Point difference & 13.703 & .00 & .455 & 0.27 & 1.000 & 0.22 & .000 & 0.69 & .455 & 0.06 & .001 & 0.48 & .000 & 0.53 \\
\hline Points scored & 5.850 & .00 & .155 & 0.33 & .142 & 0.32 & 1.000 & 0.14 & .000 & 0.62 & .013 & 0.42 & 1.000 & 0.14 \\
\hline Successful 2P field-goals & 10.980 & .00 & .000 & 0.66 & 1.000 & 0.03 & 1.000 & 0.15 & .000 & 0.74 & .001 & 0.53 & 1.000 & 0.20 \\
\hline Unsuccessful 2P field-goals & 17.761 & .00 & .000 & 0.64 & .394 & 0.24 & .235 & 0.23 & .000 & 0.9 & .000 & 0.9 & 1.000 & 0.01 \\
\hline Successful 3P field-goals & .591 & .62 & 1.000 & 0.14 & 1.000 & 0.02 & 1.000 & 0.08 & 1.000 & 0.10 & 1.000 & 0.22 & 1.000 & 0.11 \\
\hline Unsuccessful 3P field-goals & 8.569 & .00 & .000 & 0.55 & 1.000 & 0.07 & 1.000 & 0.08 & .000 & 0.65 & .001 & 0.51 & 1.000 & 0.16 \\
\hline Successful free-throws & 11.009 & .00 & .023 & 0.35 & 1.000 & 0.03 & .005 & 0.44 & .042 & 0.39 & .000 & 0.78 & .061 & 0.42 \\
\hline Unsuccessful free-throws & 17.506 & .00 & .000 & 0.68 & 1.000 & 0.09 & .270 & 0.26 & .000 & 0.59 & .000 & 0.90 & .132 & 0.35 \\
\hline Total Rebounds & 35.518 & .00 & .000 & 1.15 & .000 & 0.85 & .000 & 0.94 & .748 & 0.23 & .493 & 0.23 & 1.000 & 0.06 \\
\hline Defensive Rebounds & 13.891 & .00 & .000 & 0.58 & .000 & 0.54 & .000 & 0.44 & 1.000 & 0.06 & 1.000 & 0.19 & 1.000 & 0.13 \\
\hline Offensive Rebounds & 30.200 & .00 & .000 & 1.08 & .000 & 0.80 & .000 & 0.96 & .161 & 0.33 & 1.000 & 0.14 & 1.000 & 0.18 \\
\hline Assists & 70.379 & .00 & .000 & 1.32 & 1.000 & 0.11 & .000 & 1.34 & .000 & 1.27 & 1.000 & 0.10 & .000 & 1.29 \\
\hline Steals & 33.312 . & .00 & .000 & 1.08 & .000 & 0.67 & .000 & 1.03 & .003 & 0.48 & 1.000 & 0.12 & .073 & 0.38 \\
\hline Turnovers & 26.941 & .00 & .000 & 1.09 & 1.000 & 0.09 & .015 & 0.37 & .000 & 0.98 & .000 & 0.71 & .336 & 0.27 \\
\hline Blocks & .650 & .58 & 1.000 & 0.04 & 1.000 & 0.08 & 1.000 & 0.09 & 1.000 & 0.04 & 1.000 & 0.14 & 1.000 & 0.19 \\
\hline Fouls Committed & 18.167 & .00 & .930 & 0.20 & .081 & 0.37 & .000 & 0.72 & .003 & 0.53 & .000 & 0.82 & .054 & 0.39 \\
\hline Fouls Received & 19.163 & .00 & .411 & 0.23 & .171 & 0.32 & .000 & 0.75 & .002 & 0.50 & .000 & 0.87 & .000 & 0.43 \\
\hline Efficiency Indee & 15.178 & .00 & .000 & 0.77 & .875 & 0.23 & .000 & 0.60 & .003 & 0.56 & 1.000 & 0.09 & .011 & 0.41 \\
\hline
\end{tabular}

Table 4 shows the results of the discriminant analysis which identified three statistically significant functions. Function 1 shows the importance of assists for the prediction of belonging to Eurobasket (positive values of the centroids). Steals, total rebounds and offensive rebounds make possible the prediction of belonging to the Asia Cup and Afrobasket (negative values). The second function emphasises the 1 point throws scored and attempted, turnovers and fouls committed and received predicting belonging to Afrobasket. Finally, the third function highlights total and defensive and offensive rebounds, assists and possessions to discriminate the teams from FIBA America from the rest. 
Ibañez, S.J.; González-Espinosa, S.; Feu, S., \& García-Rubio, J. (2018). Basketball without borders? Similarities and differences among Continental Basketball Championships. RICYDE. Revista internacional de ciencias del deporte, 51(14), 42-54. https://doi.org/10.5232/ricyde2018.05104

Table 4. Structural Coefficients in FIBA continental championships

\begin{tabular}{|c|c|c|c|}
\hline & \multicolumn{3}{|c|}{$\mathrm{SCs}$} \\
\hline & Function 1 & Function 2 & Function 3 \\
\hline Possessions & -.12 & -.22 & .34 \\
\hline Successful 2P field-goals & .14 & -.27 & .19 \\
\hline Unsuccessful 2P field-goals & .07 & -.48 & .30 \\
\hline Successful 3P field-goals & .01 & -.09 & -.01 \\
\hline Unsuccessful 3P field-goals & -.11 & .27 & -.18 \\
\hline Successful free-throws & .01 & .41 & .01 \\
\hline Unsuccessful free-throws & -.07 & .50 & .04 \\
\hline Total Rebounds & -.34 & .09 & .53 \\
\hline Defensive Rebounds & -.19 & .07 & .43 \\
\hline Offensive Rebounds & -.33 & .06 & .35 \\
\hline Assists & .51 & .09 & .48 \\
\hline Steals & -.26 & .38 & -.18 \\
\hline Turnovers & -.36 & .06 & .19 \\
\hline Blocks & -.00 & .06 & .14 \\
\hline Fouls Committed & .09 & .49 & -.19 \\
\hline Fouls Received & .08 & .51 & -.16 \\
\hline Canonical Correlation & $0.793 *$ & $0.558^{*}$ & $0.345^{*}$ \\
\hline Eigenvalue & 1.698 & .452 & .135 \\
\hline
\end{tabular}

$71.0 \%$ of originally grouped cases classified correctly.

Finally, Figure 2 shows the territorial map of all the cases as a function of the continental championships. It can be seen that Afrobasket and Asia Cup are clearly differentiated from each other in function 2 and from Eurobasket in function 1. The FIBA America Championship is the one which shows intermediate values among the other 3 championships, with function 3 being the one that best discriminates it. 


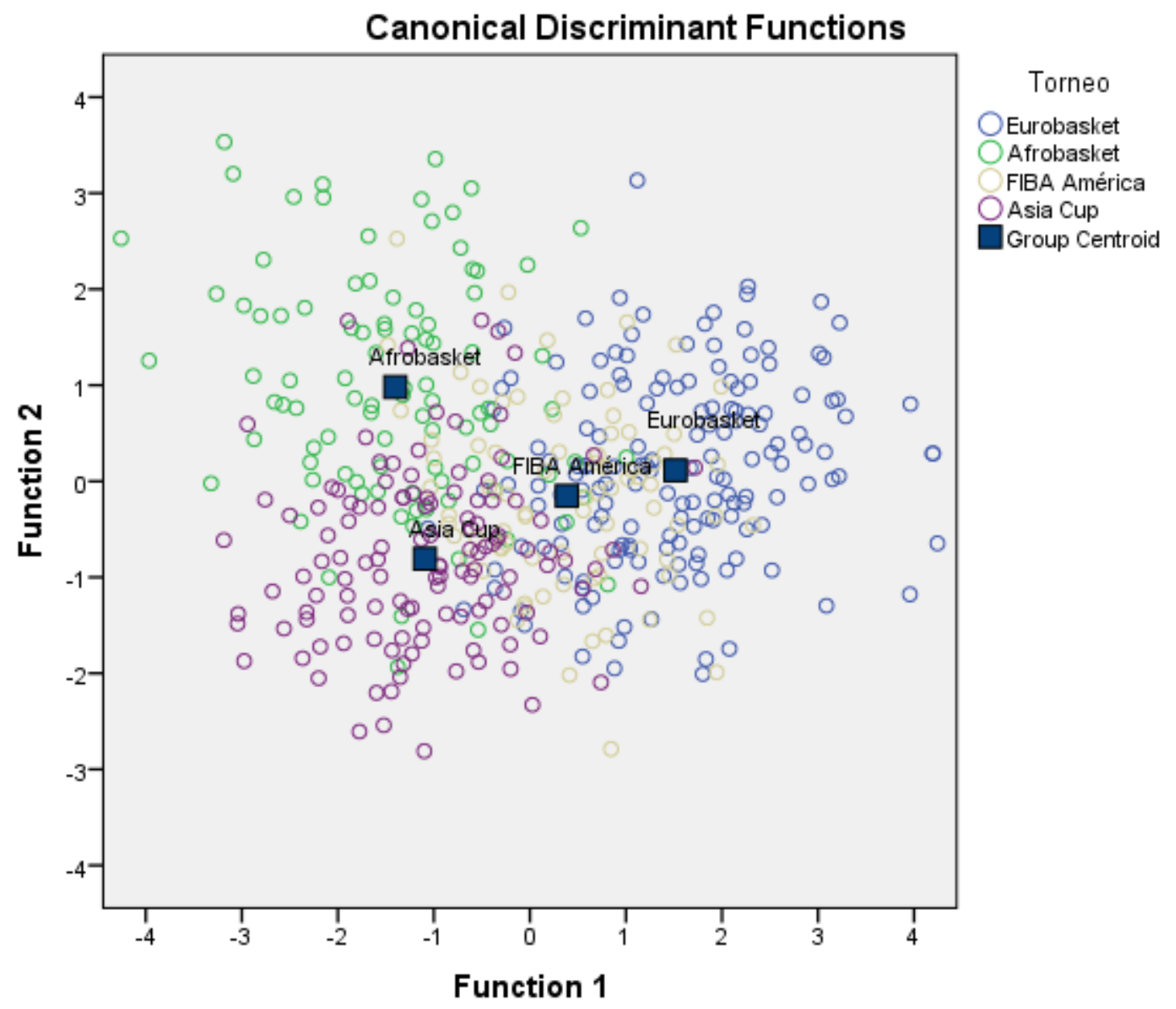

Figure 2. Territorial map of all the matches in the continental championships.

\section{Discussion}

The objective of the present study was to analyse the different continental basketball championships using TTPI, regarding differences and similarities among them. The results show that although the performance profiles are very similar among all the championships, some differences have been found. The main ones are between Eurobasket and the Asia Cup and Afrobasket championships, with the FIBA America championship revealing values somewhere in the middle.

Basketball is manifested in different ways according to the gender of the participants, the competitive level and the type of competition (García et al., 2010). Differences have been found in all the TTPI for the continental championships analysed, except in the threepoint throws scored and blocks. In fact, the scientific literature has identified different performance indicators which characterise competitions, and found that some are systematically of maximal importance in the competitions analysed to differentiate between the winners and the losers, like for example two-point throws scored and defensive rebounds (Ibáñez et al., 2003; Sampaio, et al., 2015). These performance indicators change when compare bests and worsts teams, being assists, steals and blocks are the most important (Ibáñez et al., 2008). Moreover, differences have been found as a function of the situational variables of the competition, which is also evident in this study. 
Ibañez, S.J.; González-Espinosa, S.; Feu, S., \& García-Rubio, J. (2018). Basketball without borders? Similarities and differences among Continental Basketball Championships. RICYDE. Revista internacional de ciencias del deporte, 51(14), 42-54. https://doi.org/10.5232/ricyde2018.05104

The discriminant analysis maximises the importance of assists in the European championship. Assists are important in European leagues for winning matches, and are an indicator of team play as they are passes which permit immediate scoring. Thus the teams that participate in Eurobasket play more as a team than those that participate in the rest of the continental championships. This is corroborated in studies that analyse the European leagues, like the ACB league (Spain) (García et al., 2013; Puente et al., 2015). The importance of assists has also been shown over time in the Euroleague (Štrumbelj, Vračar, Robnik-Šikonja, Dežman, \& Erčulj, 2013) or Eurobasket (Sampaio \& Leite, 2006). The main European competitions reveal the importance of assists reflecting the playing style of the teams participating in the continental competition. Assists show team work and also generate the opportunities to score and overcome the opponent's defensive strategies (García et al., 2014).

In the Asia Cup and Afrobasket championships, the most important techniques are total and offensive rebounds and steals. The steals indicate the defensive level of the team, with players who are very motivated in defence and expend a great deal of energy in this action (Gómez, Lorenzo, \& Sampaio, 2009). Steals also mark the difference in level between the participating teams. Defensive rebounds show the defensive level of the team, as they are achieved thanks to the mistakes made by the opponents caused by the excellent play by the defenders. In this case total and offensive rebounds are the actions which characterise the Asian and African championships. Offensive rebounds are a second opportunity for the attacking team to score, mainly due to mistakes in completing defensive rebounds showing a weakness in the defensive players. Similarly efforts to steal the ball in defence can leave the players badly situated for the following action, making it easier for the attackers to achieve an offensive rebound.

Following this same line of reasoning, another of the factors to be taken into account in the Asian championship is the difference among competitors. It has been found that in the European competition in 2011, 2013 and 2015, 76\% of the matches were close matches (a score difference of 15 or less points) and none of them very one-sided (a score difference of more than 40 points) (Madarame, 2017). During these same years in the Asian competition, only $45 \%$ of the matches were close and $15 \%$ were very one-sided (Madarame, 2017). The championships of Asia, Africa and America present a faster game pace than Eurobasket (according to the number of possessions), which imply that teams make more mistakes than in matches with a slower pace (according to number of turnovers) (Sampaio, Lago \& Drinkwater, 2010). The top ranked teams play with fewer possessions but with a higher offensive efficiency coefficient (Ibáñez et al., 2003). The teams normally use the strategy of playing at a slower pace when they are facing close or important matches (García et al., 2013; Sampaio \& Janeira, 2003), which occurs more frequently in Europe, with differences between winners and losers of 11.61 points, whereas in the Asia Cup this difference rises to 21.51 points. The European championship shows a mean of 1.4 field goals per assist, while the African value is 1.8 and the Asian 2.2. This demonstrates that the teams achieve more points after an individual action or an offensive rebound, and in these championships team work is less important.

The American championship shows intermediate values compared with the above mentioned championships. Studies on American basketball, to be precise on the most important league in the world the NBA, have found that the winning teams are characterised by better offensive efficiency, especially in the points scored in the third quarter, as well as standing out regarding fouls and steals (Mikołajec et al., 2013). In other leagues on the American continent, it has been shown that efficiency in throws, rebounds, 
Ibañez, S.J.; González-Espinosa, S.; Feu, S., \& García-Rubio, J. (2018). Basketball without borders? Similarities and differences among Continental Basketball Championships. RICYDE. Revista internacional de ciencias del deporte, 51(14), 42-54. https://doi.org/10.5232/ricyde2018.05104

steals and assists discriminate the winner from the losers in the Brazilian league (De Rose, 2004), or that in Chilean basketball many points are scored per possession (Fernández, Ortega, Ubal, Gómez, \& Ibáñez, 2010). In the Costa Rican league the importance of throws and the better performance of the winning team in the second half of the match were identified (Romero, Bonilla, Cabrera, \& Ureña, 2011). Studies on the different American leagues are scarce with the exception of the NBA, but those which have been found highlight the importance of goals attempted, and the American championship is the one that presents the highest percentage of field goals attempted, above that of Eurobasket.

\section{Conclusions and practical applications}

The present study identifies the performance profiles of each continental championship, and has discovered that each one has a specific performance profile, meaning that the game is played differently in each region of the world. In short, basketball is a dynamic sport which changes according to the part of the world in which it is played. Although it is the same sport, played to the same rules, the determinants of success or failure and the playing styles are different on each continent. The results indicate that in Europe basketball teams are more similar in level and team work (assists) is of paramount importance. In closer competitions, like Eurobasket, the games are played with a greater control of the pace, and less possessions. In the rest of the continents basketball seems to be less organised, with the individual player gaining greater importance than the team and where more mistakes are made (total rebounds, steals, evaluation...).

The results of this study can help national team managers to better prepare for the home competition, and have information on the most important performance indicators at any one moment. When it comes to playing in world championships, against national teams from all the continents, like the Olympic Games or the FIBA Basketball World Cup, coaches can use these data to get to know their opponents better according to the continent they come from and thus prepare the match in a specific and detailed manner.

\section{Limitations.}

As a limitation, it should be mentioned that this study has a purely quantitative approach, which provides valid and objective information, but it should be complemented with another type of qualitative analysis to contribute information about how and why. Furthermore, a detailed study of the performance indicators, according to the final result of the match or the final point difference on the scoreboard, would provide additional information which would be of use to coaches.

\section{Acknowledgements}

This study has been partially subsidised by Aid for Research Groups [Ayuda a los Grupos de Investigación] (GR15122) from the Junta de Extremadura (Consejería de Economía e Infraestructuras); with a contribution from the European Union through FEDER.

\section{References}

Ato, M.; López-García, J. J., \& Benavente, A. (2013). Un sistema de clasificación de los diseños de investigación en psicología. Anales de Psicología, 29(3), 10381059. https://doi.org/10.6018/analesps.29.3.178511 
Ibañez, S.J.; González-Espinosa, S.; Feu, S., \& García-Rubio, J. (2018). Basketball without borders? Similarities and differences among Continental Basketball Championships. RICYDE. Revista internacional de ciencias del deporte, 51(14), 42-54. https://doi.org/10.5232/ricyde2018.05104

De Rose, D. (2004). Statistical analysis of basketball performance indicators according to home/away games and winning and losing teams. Journal of Human Movement Studies, 47, 327-336.

Drust, B. (2010). Performance analysis research: meeting the challenge. Journal of Sport Science, 28(9), 1-2.

https://doi.org/10.1080/02640411003740769

Fernández, R.; Ortega, E.; Ubal, M.; Gómez, M. A., \& Ibáñez, S. J. (2010). Estudio descriptivo de la utilización de factores defensivos en la división mayor del básquetbol chileno (Dimayor). Kronos, 9(17), 68-75.

Field, A. (2013). Discovering statistics using IBM SPSS statistics. London: SAGE Publications Ltd.

García, J.; Ibáñez, S. J.; Gómez, M. A., \& Sampaio, J. (2014). Basketball Gamerelated statistics discriminating $A C B$ league teams according to game location, game outcome and final score differences. International Journal of Performance Analysis in Sport, 14(2), 443-452.

García, J.; Ibáñez, S. J.; Martinez De Santos, R.; Leite, N., \& Sampaio, J. (2013). Identifying basketball performance indicators in regular season and playoff games. Journal of Human Kinetics, 36(1), 161-168.

https://doi.org/10.2478/hukin-2013-0016

García, J.; Ibáñez, S. J.; Parejo, I.; Cañadas, M., \& Feu, S. (2010). Análisis de los Campeonatos del Mundo de baloncesto masculino (2002 y 2006). Diferencias entre expertos y noveles (sénior y junior). Motricidad. European Journal of Human Movement (24), 133-145.

García, J.; Sáez, J.; Ibáñez, S. J.; Parejo, I., \& Cañadas, M. (2009). Home advantage analysis in ACB league in season 2007-2008. Revista de Psicología del Deporte, 18, 331-335.

García, J.; Cañadas, M., \& Antúnez, A. (2015). Efectos de la asistencia, densidad de la misma y la capacidad del pabellón en las victorias conseguidas en casa en función de la conferencia en la NBA. [Effects of attendance, crowd density and capacity of arena in home advantage according to NBA conference. Cuadernos de Psicología del Deporte, 15(3), 175-180.

https://doi.org/10.4321/S1578-84232015000300018

Gómez, M.; Lorenzo, A., \& Sampaio, J. (2009). Análisis del rendimiento en baloncesto ¿Es posible predecir los resultados. Sevilla: Wanceulen.

Gómez, M. A.; Lorenzo, A.; Ortega, E.; Sampaio, J., \& Ibáñez, S. J. (2009). Game related statistics discriminating between starters and nonstarters players in Women's National Basketball Association League (WNBA). Journal of Sports Science and Medicine, 8, 278-283.

Gómez, M. A.; Lorenzo, A.; Sampaio, J.; Ibáñez, S. J., \& Ortega, E. (2008). Gamerelated statistics that discriminated winning and losing teams from the Spanish men's professional basketball teams. Collegium Antropologicum, 32(2), 451-456.

Hughes, M.; Evans, S., \& Wells, J. (2001). Establishing normative profiles in performance analysis. International Journal of Performance Analysis in Sport, 1(1), $1-26$.

Hughes, M., \& Franks, I. (2007). The essentials of performance analysis: an introduction. London: Routledge.

Ibáñez, S. J.; Feu, S., \& Dorado, G. (2003). Análisis de las diferencias en el juego en función del género y categoría. Iberian Congress on Basketball Research, 2, 7388. 
Ibañez, S.J.; González-Espinosa, S.; Feu, S., \& García-Rubio, J. (2018). Basketball without borders? Similarities and differences among Continental Basketball Championships. RICYDE. Revista internacional de ciencias del deporte, 51(14), 42-54. https://doi.org/10.5232/ricyde2018.05104

Ibáñez, S. J.; García, J.; Feu, S.; Parejo, I., \& Cañadas, M. (2009). Shot efficacy in the NBA: A multifactorial analysis. Cultura, Ciencia y Deporte, 10, 39-47.

Ibáñez, S. J.; Sáenz-López, P.; Giménez, J.; Sampaio, J., \& Janeira, M. A. (2003). Game statistics discriminating the final outcome of Junior World Basketball Championship matches (Portugal'99). Journal Human Movement Studies, 45, 0119.

Ibáñez, S. J.; Sampaio, J.; Feu, S.; Lorenzo, A.; Gómez, M. A., \& Ortega, E. (2008). Basketball game-related statistics that discriminate between teams' season long success. European Journal of Sport Science, 8(6), 1-4.

Lago-Peñas, C., \& Lago-Ballesteros, J. (2011). Game location and team quality effects on performance profiles in professional soccer. Journal of Sports Science \& Medicine, 10(3), 465.

Liu, H.; Yi, Q.; Giménez, J.-V.; Gómez, M.-A., \& Lago-Peñas, C. (2015). Performance profiles of football teams in the UEFA Champions League considering situational efficiency. International Journal of Performance Analysis in Sport, 15(1), 371-390.

Madarame, H. (2017). Game-Related Statistics Which Discriminate Between Winning and Losing Teams in Asian and European Men's Basketball Championships. Asian Journal of Sports Medicine (In Press). https://doi.org/10.5812/asjsm.42727

Mikołajec, K.; Maszczyk, A., \& Zając, T. (2013). Game indicators determining sports performance in the NBA. Journal of Human Kinetics, 37(1), 145-151. https://doi.org/10.2478/hukin-2013-0035

Ntoumanis, N. (2001). A step-by-step guide to SPSS for sport and exercise studies. London: Routledge

O'Donoghue, P. (2005). Normative profiles of sports performance. International Journal of Performance Analysis in Sport, 5(1), 104-119.

Oliver, D. (2004). Basketball on paper: rules and tools for performance analysis: Potomac Books, Inc.

Puente, C.; Coso, J. D.; Salinero, J. J., \& Abián-Vicén, J. (2015). Basketball performance indicators during the ACB regular season from 2003 to 2013. International Journal of Performance Analysis in Sport, 15(3), 935-948. https://doi.org/10.1080/24748668.2015.11868842

Randolph, J. J. (2005). Free-Marginal Multirater Kappa (multirater kfree): An Alternative to Fleiss' Fixed-Marginal Multirater Kappa. Paper presented at the Joensuu Learning and Instruction Symposium 2005, Joensuu, Finland.

Ribeiro, H. V.; Mukherjee, S., \& Zeng, X. H. T. (2016). The Advantage of Playing Home in NBA: Microscopic, Team-Specific and Evolving Features. PloS One, 11(3). https://doi.org/10.1371/journal.pone.0152440

Romero, L. B.; Bonilla, P. U.; Cabrera, J. S., \& Ureña, B. S. (2011). Perfil de rendimiento técnico del equipo tetracampeón de la liga superior de baloncesto de Costa Rica. MHSALUD: Revista en Ciencias del Movimiento Humano y Salud, 8(2).

Sampaio, J.; Ibáñez, S. J., \& Feu, S. (2004). Discriminative power of basketball game-related statistics by level of competition and sex. Perceptual and Motor Skills, 99(3), 1231-1238.

https://doi.org/10.2466/pms.99.3f.1231-1238 
Ibañez, S.J.; González-Espinosa, S.; Feu, S., \& García-Rubio, J. (2018). Basketball without borders? Similarities and differences among Continental Basketball Championships. RICYDE. Revista internacional de ciencias del deporte, 51(14), 42-54. https://doi.org/10.5232/ricyde2018.05104

Sampaio, J., \& Janeira, M. (2003). Statistical analyses of basketball team performance: understanding teams' wins and losses according to a different index of ball possessions. International Journal of Performance Analysis in Sport, 3(1), 40-49.

Sampaio, J.; Lago, C., \& Drinkwater, E. J. (2010). Explanations for the United States of America's dominance in basketball at the Beijing Olympic Games (2008). Journal of Sports Sciences, 28(2), 147-152.

https://doi.org/10.1080/02640410903380486

Sampaio, J., \& Leite, N. M. C. (2006). ¿Por qué ganaron o perdieron los partidos de baloncesto los equipos que participaron en el Eurobasket 2005? Kronos, 5(9), 6773.

Sampaio, J.; McGarry, T.; Calleja-González, J.; Jiménez, S.; Schelling, X., \& Balciunas, M. (2015). Exploring game performance in the National Basketball Association using player tracking data. PloS-One, 10(7).

https://doi.org/10.1371/journal.pone.0132894

Štrumbelj, E.; Vračar, P.; Robnik-Šikonja, M.; Dežman, B., \& Erčulj, F. (2013). A decade of euroleague basketball: An analysis of trends and recent rule change effects. Journal of Human Kinetics, 38, 183-189.

https://doi.org/10.2478/hukin-2013-0058

Tabachnick, B. G.; Fidell, L. S., \& Osterlind, S. J. (2001). Using multivariate statistics. Boston: Pearson.

Thalheimer, W., \& Cook, S. (2002). How to calculate effect sizes from published research: A simplified methodology. Work-Learning Research, 1-9. Retrieved December 1, 2016 from: http://work-learning.com/effect_sizes.htm 